\title{
Consumer Willingness to Pay for Beef Grown Using Climate Friendly Production Practices
}

\author{
Xiaogu Li ${ }^{\mathrm{a}}$, Kimberly L. Jensen ${ }^{\mathrm{b} *}$, Christopher D. Clark ${ }^{\mathrm{b}}$, Dayton M. Lambert ${ }^{\mathrm{b}}$ \\ ${ }^{a}$ Department of Agricultural Economics, Sociology, and Education, Armsby Building, \\ Pennsylvania State University, University Park, PA 16802, United States. \\ ${ }^{\mathrm{b}}$ Department of Agricultural \& Resource Economics, 302 Morgan Hall, The University of \\ Tennessee, Knoxville, TN 37996, United States. \\ *Corresponding author. Tel: +1 8659747231 \\ E-mail addresses : xq15271@ psu.edu (X. Li), kjensen@utk.edu (K. Jensen), cdclark@utk.edu (C. \\ Clark), dlamber1@utk.edu (D. Lambert)
}

Acknowledgement: Funding for this study was provided in part by a grant from the USDA NIFA Agriculture and Food Research Initiative Competitive Grants Program, Grant Number: GRANT10642663. The views expressed in this article are those of the co-authors.

(C) 2016. This manuscript version is made available under the Elsevier user license http://www.elsevier.com/open-access/userlicense/1.0/ 


\begin{abstract}
The cattle industry contributes to U.S. agricultural greenhouse gas (GHG) emissions. Prescribed grazing can help reduce GHG emissions. We examine a hypothetical third party certified labeling program for beef from livestock operations using prescribed grazing. Willingness to support and pay for beef with the label is estimated using data from a survey of U.S. consumers. The findings are encouraging for producers and retailers pursuing niche markets for beef products. Estimated annual household willingness to pay is $\$ 306$ among program supporters and $\$ 64$ among all beef-consuming households. Support and willingness to pay are influenced by demographics, attitudes toward the environment and food production-distribution system, as well as perceived policy consequences of their survey responses.
\end{abstract}

Keywords: Beef, GHG Emissions, Willingness to Pay, Consequentiality 


\section{Consumer Willingness to Pay for Beef Grown Using Climate Friendly Production Practices}

\section{Introduction}

From 2009 to 2013 , U.S. livestock production accounted for approximately 2 percent of U.S. GHG emissions and 26 percent of emissions from U.S. agriculture (US EPA 2015). Changes in beef cattle production, especially a switch to prescribed grazing, can reduce U.S. agricultural greenhouse gas emissions by reducing emissions from enteric fermentation and manure management and by sequestering carbon on grazing lands. Grazing lands currently cover approximately one-third of U.S. land area (Nickerson et al. 2011) and already store large amounts of carbon and could sequester much more (Follett and Reed 2011) with improved grazing management (Ma and Coppock 2012, Morgan et al. 2010). However, estimates from prior research on program costs to encourage farmers to add 10.4 million acres of prescribed grazing was \$520 million per year (Jensen et al., 2015). In this paper we examine whether consumers are willing to pay for beef produced using grazing practices that mitigate GHG emissions and increase carbon sequestration.

In light of the potential for changes in grazing management to reduce GHG emissions and increase carbon sequestration, this study examines consumer willingness to pay (WTP) for beef produced using grazing practices that mitigate GHG emissions and increase carbon sequestration. Specifically, the effect of a hypothetical, third party, beef certification program "Raised Carbon Friendly" (RCF) - on the WTP for two different beef products is evaluated using the results of a contingent valuation experiment from a national survey of U.S. beef consumers. Survey respondents were informed that the RCF certification would be awarded to beef produced from cattle raised using prescribed grazing practices.

Prescribed grazing is an example of a management practice that can reduce GHG emissions from cattle grazing and increase the amount of carbon sequestered on pastureland by 
controlling the harvest of vegetation (USDA/NRCS, 2010). Farmers who adopt prescribed grazing manage vegetation harvest by rotating cattle through different paddocks and maintaining minimum forage grazing heights. Under this system, forage grows for a longer period during the grazing season, improving forage quality and quantity. Increased forage quantities augment carbon storage in soils, in turn offsetting GHG emissions associated with livestock production (Briske et al., 2013). Research also suggests that methane emissions from cattle produced with prescribed grazing systems may be lower than cattle fed on conventional pasture systems (Cottle, Nolan, and Wiedemann, 2011).

Despite these and other environmental benefits, such as reductions in soil erosion, farmers may be reluctant to adopt prescribed grazing because of the startup and maintenance costs prescribed grazing entails. ${ }^{1}$ However, prior research suggests that beef cattle producers have an interest in mitigating GHG emissions from cattle production through the implementation of management-intensive grazing practices (Jensen et al., 2015). This interest could be driven by increasing concerns about the possibility of regulatory efforts to mitigate climate change (e.g., Hibbs et al., 2014; Niles et al., 2013) and a preference for voluntary, market-based incentive programs. A third-party voluntary labeling program of beef products could provide a marketbased alternative to regulation that would encourage producers to reduce GHG emissions from their cattle operations, assuming consumers are willing to pay a premium for beef raised with practices that reduce GHG emissions. This study addresses one aspect of the feasibility of such a program by analyzing consumer WTP for RCF-certified beef.

\section{Previous Studies}

Prescribed Grazing and GHG Emissions

\footnotetext{
${ }^{1}$ These costs include costs associated with forage seeding and fertilization, weed control, increased fencing, the installation of water tanks in paddocks, protection of intensively used areas, and the additional labor needed to move cattle among paddocks (USDA/NRCS, 2013).
} 
Beef production is a significant contributor to GHG emissions, but increases in the efficiency of beef production have reduced GHG emissions per unit of beef produced. Capper (2011) estimated that the carbon footprint of U.S. beef production system from manufacturing of crop inputs to the animal arriving at the slaughterhouse fell 16.3 percent from 1977 to 2007. Desjardins et al. (2012) estimated that the carbon footprint of Canadian beef cattle production (cradle to farm-gate) decreased by nearly 50 percent from 1981 to 2006.

The reduced carbon footprints per pound of beef are due to several factors, including improved cattle genetics, more extensive use of sustainable land management practices, and less time for grain-finished cattle to reach market weight relative to grass-finished cattle. For this reason, cattle finished in feedlots generally have a lower carbon footprint than cattle finished in a pasture. Capper (2012) estimated the carbon footprint for U.S. grain-finished cattle to be 60 percent of that for grass-finished cattle. Pelletier, et al. (2010) found that the carbon footprint for grain-finished cattle in the Upper Midwestern U.S. was 23 percent lower than for cattle finished on pasture. However, Pelletier et al. (2010, p. 388) acknowledge the possibility of "substantial reductions in net greenhouse gas emissions for pasture systems under conditions of positive soil organic carbon sequestration potential (i.e. following changes in land use, but with declining sequestration rates over time).”

The potential for management-intensive grazing to sequester more carbon than continuous, extensive grazing is one reason why some studies suggest that the improved management of grazing land will increase their potential to sequester atmospheric carbon and accumulate soil organic matter. Management-intensive grazing can increase soil organic carbon through increased plant production and the rapid incorporation of manure (Oates and Jackson, 2014). Total soil carbon sequestration is also higher with management-intensive grazing than 
with extensive grazing (Conant et al., 2003; Wienhold et al., 2001; Liebig et al., 2006). A number of studies conclude that management-intensive grazing could reduce the carbon footprint for beef cattle production. Phetteplace et al. (2001) found that the use of management-intensive grazing during the cow-calf phase could reduce emissions per live weight gain by 10 percent and sequester enough carbon to offset as much as 15 to 30 percent of the GHG emissions associated with cow-calf production. DeRamus et al. (2003) reported that a management-intensive grazing system in Louisiana could reduce enteric methane emissions by 22 percent compared to continuous grazing. Oates and Jackson (2014) found that management-intensive grazing in Wisconsin performed significantly better in terms of carbon storage and loss than continuous grazing. Dick et al. (2015) found that the use of rotational grazing in southern Brazil reduced GHG emissions associated with livestock production.

\section{Carbon Footprints and Consumer WTP for Food Products}

Research suggests that the provision of information about the carbon footprint of consumer products can influence demand for those products (e.g., Aoki and Akai, 2013; Kimura et al., 2010; Lanz et al., 2014; Matsdotter et al., 2014; Nishino, Akai and Tamura, 2014; Panzone et al., 2011; Perino et al., 2014; Saunders et al., 2010; Spaargaren et al., 2013; Vanclay et al., 2011). For example, using the results of field experiments with shoppers in seven London supermarkets, Panzone et al. (2011), Perino et al. (2014), and Lanz et al. (2014) found that carbon footprint labeling increased the market share of low carbon options for soft drinks, spreads (margarine and butter), milk, and meat (fresh chicken and beef). On the other hand, using scanner data from a supermarket chain in the United Kingdom, Kortelainen, et al. (2015) found that a carbon label had no impact on detergent prices or demand. A number of studies using hypothetical market experiments find a positive WTP for low carbon varieties of food 
products, including pork products in Finland (Koistinen et al., 2013), chicken breasts in Holland (Van Loo et al., 2014), ground beef in Canada (Grebitus et al., 2013), apples and tomatoes in the U.S. (Onozaka and McFadden, 2011), milk and bread in Chile (Echeverría et al., 2014). Thus, the introduction of a carbon label on beef products could influence consumer purchase decisions, especially given that consumers likely know little about the actual carbon footprints of beef or beef substitutes (Sharp and Wheeler, 2013).

Consumers concerned about the carbon footprint of their food consumption could attempt to reduce their carbon footprint by reducing their consumption of beef and dairy products (Environmental Working Group, 2011; Garnett, 2011; Jones and Kammen, 2011; Heller and Keoleian, 2015). For example, approximately 30 percent of respondents to a 2014 multinational survey considered meat and dairy production major contributors to climate change and over half of the respondents were either already eating less meat or considered themselves likely to eat less meat in the future (Bailey et al., 2014). A study of meat consumers in the Netherlands revealed a negative relationship between the frequency of meat consumption and belief in climate change or concern for the environment (De Boer et al., 2013). Thus, some consumers might choose to consume less beef even with the availability of low carbon beef options.

Consumers with little familiarity with, or concern about, climate change may be less likely to support a label for low-carbon beef (Mäkiniemi and Vainio, 2013; Kessler et al., 2013). Consumers who are motivated to reduce their carbon footprint might also support a program but not necessarily be willing to pay a price premium for lower carbon beef given that they might achieve greater reductions in their carbon footprint by substituting other less carbon-intensive foods for beef. For example, Chalmers et al. (2014) found that Scottish consumers preferred to switch to a lower carbon milk substitute, soy milk, instead of paying a premium for more 
expensive, lower emission dairy milk. Moreover, increased awareness of the "disproportionate" share of GHG emissions associated with beef production, as might come from a broader carbon labeling program, may encourage consumers most concerned about climate change to reduce or even forgo beef consumption altogether.

Our hypothesis is that beef consumers concerned about the environment and who believe climate change is occuring will generally support the hypothetical RCF program analyzed in this research. Thus, while we would expect support among consumers for the RCF program, it is unclear that this support would translate into WTP a premium for RCF beef. The empirical approach differentiates consumers who are not supportive of the program from those who are and those who are supportive but not willing to pay a premium for RCF beef from those who are on the basis of demographics (e.g., age, education, household income) and attitudes towards

climate change, food safety, and agricultural policy. This approach enables analysis of the extent to which these factors are associated with both support for the RCF program and WTP a price premium for RCF beef among consumers who support the program.

\section{Data and Survey Methods}

Data were collected through an online survey hosted by GfK $^{\circledR}$ Custom Research, LLC (GfK) during April and May of 2013. GfK used both address-based sampling techniques from a sample frame of the U.S. Postal Service's Delivery Sequence File and list-assisted random-digit dialing techniques based on a sample frame of the U.S. residential landline telephone universe to recruit individuals aged eighteen years or older by probability-based sampling representing the U.S. population. Combining the two sampling frames has the advantage of reducing the variance of associated adjustment weights and aligns the sample more closely to the overall demographic distribution in the population. Households with a home computer and Internet access were asked 
to complete the survey using their own equipment and Internet connection. Households without a computer and access to the Internet were provided a laptop computer and free monthly Internet access in exchange for completing surveys. Incentive points per survey redeemable for cash were provided to respondents for completing surveys.

Panel members selected for the survey were contacted by a personalized e-mail invitation with an Internet link to the survey. Individuals responding to the invitation were asked if they or other members of their household consumed beef. Households with beef consumers continued to the survey while those without were asked to provide reasons why they did not eat beef and then dismissed. A total of 1,705 households were invited to participate in the survey, with 956 households responding. Of these households, 905 qualified as beef consumers. The survey completion rate was 56 percent and the qualification rate was 95 percent. The final sample size for this study was 806 after eliminating records with missing values. ${ }^{2}$

The survey began with questions about household consumption of beef products, including the number of household meals in a typical week that included beef, monthly household expenditures on food (food consumed at home), expenditures on beef products as a percentage of total household food expenditures, and the average monthly household expenditures on beef. Respondents were provided information about average U.S. household food expenditures to help them formulate responses to these questions. The beef consumption questions were followed by a screen providing information on U.S. GHG emissions and the percentage of these emissions attributable to beef production (Figure 1). Respondents were then asked if this information accorded with their pre-survey expectations about GHG emissions associated with beef production. A second information screen focused on the potential effects of

2 The survey is available from the authors. 
prescribed grazing on GHG emissions from cattle production followed (Figure 2). Respondents were then provided an option to access additional information on prescribed grazing. ${ }^{3}$

Respondents who chose to access the additional information were shown the following text:

Prescribed grazing systems allow animals to graze only a small portion of the pasture (an individual paddock) while vegetation in the other paddocks is rested and allowed to recover. Resting grazed land allows the vegetation to renew energy reserves, rebuild shoot systems, and deepen root systems, with the end result being long-term maximum biomass production. Pasturelands managed using prescribed grazing can become better stores of carbon compared with conventional lands, offsetting GHG emissions from other sources.

The information screens explaining prescribed grazing and GHG emissions were followed by an information screen introducing a hypothetical program that would compensate farmers for producing beef using prescribed grazing and certify the beef they produced as "Raised Carbon Friendly" (Figure 3). This information screen was followed by a question asking respondents about their support for the RCF program and willingness to pay more for RCFcertified beef. The question had three response options allowing respondents to indicate whether they: (i) did not support the program and were unwilling to pay more for RCF-certified beef; (ii) supported the program but were unwilling to pay more for RCF-certified beef; or (iii) supported the program and were willing to pay more for RCF-certified beef. A reminder about budgets is useful when surveying respondents who have limited experience with contingent valuation questions (List 2001; List and Gallet 2001). Thus, respondents indicating willingness to pay

\footnotetext{
3 The information on GHG emissions and the effects of the adoption of prescribed grazing on GHG emissions was based on Gurian-Sherman (2011), Conant et al. (2003), Conant et al. (2001), and Undersander et al. (2002).
} 
more for RCF-certified beef were prompted with a "cheap talk" screen to mitigate $e x$-ante potential hypothetical bias associated with "yea-saying" (Cummings and Taylor, 1999) before continuing to the valuation exercise.

Open-ended WTP questions can result in high fractions of income being stated because there is no upper bound on the amount respondents could state they would pay (Loomis 2014). Loomis also notes that using a referendum form of the CVM can help reduce hypothetical bias in CVM survey derived estimates of WTP. Hence, we employed a closed-ended referendum approach. Given the complexity of the program concepts, we opted to keep the choice exercise complexity down and used a single-bounded approach.

The CV question provided respondents with an estimate of their current annual household expenditures on beef equal to twelve times the amount they had previously asserted as their household's monthly beef expenditures. Respondents were then asked whether they would be willing to pay, on an annual basis, an additional specified dollar amount for RCF-certified beef (the CV bid). CV bids were determined by randomly assigning a percentage $(5 \%, 10 \%, 20 \%$, $30 \%$, or $40 \%$ ) to each respondent and multiplying the percentage by their estimated current annual household beef expenditures. The CV bids offered averaged $\$ 128.44$ per household per year. Respondents chose from "yes" or "no" options to the valuation question. Respondents choosing the "no" option were asked to list the reasons why they were unwilling to pay the premium.

The valuation exercise was followed by a series of attitudinal questions asking respondents to indicate on a Likert-scale ( $1=$ Strongly Disagree,,.., $5=$ Strongly Agree $)$ the extent to which they agreed with statements about the U.S. food industry, food safety, government policies on food production and environment, climate change, and distribution of the 
costs of environmental protection. The survey concluded with questions about their personal contributions of time or money to environmental organizations and sources of information about environmental issues.

\section{Modeling Framework}

A two-tiered system of equations was developed to estimate WTP for RCF beef. The first tier is a standard case-specific multinomial probit (MNP) model following Bunch (1991), Kamamura (1989), and McFadden (1981). Individual $i$ attributes utility $(U)$ to alternative $j=1$ ("Does not support RCF-certified beef”), 2 (“Supports but will not pay more for RCF-certified beef”) or 3 (“Supports and will pay more for RCF-certified beef”). The latent variables associated with the level of indirect utility derived from choice $j$ are linear in terms,

$$
\begin{aligned}
& U_{i 1}^{*}=\theta_{1}{ }^{\prime} X_{i}+\xi_{i 1}, \\
& U_{i 2}^{*}=\theta_{2}{ }^{\prime} X_{i}+\xi_{i 2}, \\
& U_{i 3}^{*}=\theta_{3}{ }^{\prime} X_{i}+\xi_{i 3},
\end{aligned}
$$

where $X_{i}$ is a matrix of respondent attributes, $\theta_{j}$ a vector of parameters, and $\xi_{i j}$ a stochastic component of utility. Individual $i$ chooses $j$ if $U_{i j}^{*}>U_{i j^{\prime}}^{*}$ for all $j^{\prime} \neq j$. Choice $j=3$ determines the likelihood of respondents not only supporting but also willing to pay more for beef from producers participating in the RCF program. These respondents are the set of consumers defining the market for RCF-certified beef.

Choice 3 of the MNP is a selection mechanism for the second tier of the model where WTP for RCF-certified beef is estimated with single-equation probit regression. Respondent WTP is only observed in the second-tier probit model if the individual supports the RCF program and is willing to pay some additional amount for the certified product (i.e., $j=3$ ). The dependent variable of the WTP probit model is a binary variable; respondents choose "yes" or 
"no" to the bid amounts offered. The probability that the individual would accept and pay the WTP bid (i.e., choose “yes"), is:

$$
\operatorname{Pr}\left(\text { Accept }_{i}=1\right)=\operatorname{Pr}\left(v\left(M_{i}-\text { Bid }_{i}, Z_{i}\right)+\varepsilon_{i 0} \geq v\left(M_{i}, Z_{i}\right)+\varepsilon_{i 1}\right),
$$

where $v(\cdot)$ is the utility individual $i$ receives from accepting or rejecting the bid, $M_{i}$ is $i$ 's disposable income or wealth, $Z_{i}=\left(z_{i 1}, \ldots, z_{i k}\right)^{\prime}$ is a vector of respondent characteristics, $B i d_{i}$ is the amount offered, and $\left(\varepsilon_{i 0}, \varepsilon_{i 1}\right)$ are i.i.d. random error terms with zero means and constant variances (Hanemann, 1984). Equivalently, the change in indirect utility on the probability of accepting the bid is:

$$
\operatorname{Pr}\left(\text { Accept }_{i}=1\right)=\Phi\left(\Delta v^{*}\right)=\Phi\left(\beta_{0}+\beta_{p} \cdot B_{i d_{i}}+Z_{i}^{\prime} \beta\right),
$$

where $\Delta v^{*}=v\left(M_{i}-\operatorname{Bid}_{i}, Z_{i}\right)-v\left(M_{i}, Z_{i}\right), \Phi(\cdot)$ is the standard normal cumulative distribution function (c.d.f.), and $\left(\beta_{0}, \beta_{p}, \beta\right)$ are parameters.

\subsection{Identification and estimation}

Standard application of the case-specific MNP requires that the error terms of an arbitrary category are normalized because scale and level of utility are irrelevant with respect to the choices among alternatives individuals make (Train, 2003). The base category is $j=1$,

$$
\begin{aligned}
& U_{i 2}^{*}=\left(\theta_{2}-\theta_{1}\right)^{\prime} X_{i}+\xi_{i 2}^{*}, \\
& U_{i 3}^{*}=\left(\theta_{3}-\theta_{1}\right)^{\prime} X_{i}+\xi_{i 3}^{*},
\end{aligned}
$$

where $\xi_{i j}^{*}=\xi_{i j}-\xi_{i 1}$. The covariance terms of the $\xi_{i j}^{*}$ 's are not identified because the systematic portion of utility only contains case-specific variables (Long and Freese 2014). Eliminating alternative 1 using Train's (2003, p. 113-114) procedure, the covariance matrix of the $\xi_{i j}^{*}$ 's is the matrix with elements $\operatorname{var}\left(\xi_{i 2}^{*}\right)=\operatorname{var}\left(\xi_{i 3}^{*}\right)=2$ and $\operatorname{cov}\left(\xi_{i 2}^{*}, \xi_{i 3}^{*}\right)=1$ (Roodman 2011). This normalization maintains the independence of irrelevant alternatives assumption. 
The WTP probit equation is estimated for the subset of respondents who supported the program and were willing to pay an additional amount for RCF beef (choice $j=3$ ). The conditionality of the bid acceptance on the first-tier choice of $j=3$ suggests a selection mechanism with respect to the decision to accept the bid from the consumption or level of expenditure decision (Blaylock and Blisard, 1992). Screening questions help identify if a respondent would actually be identified in a specific market to reduce respondent burden and to reduce yea-saying (Blamey, Bennett, and Morrison, 1999). For example, some individuals would never smoke no matter how cheap cigarettes were; these individuals do not belong to the market for cigarettes. The screening mechanism distinguishes these individuals (i.e., those for whom WTP is equal to zero) from consumers whose reservation price has not been met (Jensen et al., 2015). The latent variable Accept* is therefore conditioned on the likelihood a respondent indicated their support for and willingness to pay a premium for RCF beef;

$$
\operatorname{Accept}_{i}^{*}=\beta_{0}+\beta_{p} \cdot \text { Bid }_{i}+Z_{i}^{\prime} \beta+\eta_{i}, \text { Accept }_{i}=\left\{\begin{array}{l}
1 \text { if } \text { Accept }_{i}^{*}>0, U_{i 3}^{*}>0 \\
0 \text { if } \text { Accept }_{i}^{*} \leq 0, U_{i 3}^{*}>0
\end{array}\right.
$$

with the standard single-equation probit normalization $\eta_{i}=\varepsilon_{i 1}-\varepsilon_{i 0}$ and $\operatorname{Var}\left(\eta_{i}\right)=1$ (Goldberger, 1964).

The choice structure suggests the error terms are multivariate normal (MVN) distributed:

$$
\left[\begin{array}{l}
\xi_{i 2}^{*} \\
\xi_{i 3}^{*} \\
\eta_{i}
\end{array}\right] \sim \operatorname{MVN}\left(\left[\begin{array}{l}
0 \\
0 \\
0
\end{array}\right],\left[\begin{array}{ccc}
2 & 1 & 0 \\
1 & 2 & \sqrt{2} \rho_{3 \eta} \\
0 & \sqrt{2} \rho_{3 \eta} & 1
\end{array}\right]\right)
$$

which implies $\operatorname{corr}\left(\xi_{i 2}^{*}, \xi_{i 3}^{*}\right)=0.5$ and $\operatorname{corr}\left(\eta, \xi_{i 3}^{*}\right)=\rho_{3 \eta}$. (See the Appendix for the derivation.) The correlation parameter is identified by omitting elements from the determinants of the multinomial choice set $(X)$ from respondent characteristics determining willingness to accept a bid (Z) (details follow). 
The parameter vector $\gamma=\left(\theta_{2}, \theta_{3}, \beta_{0}, \beta_{p}, \beta, \rho_{3 \eta}\right)$ is estimated with maximum likelihood. The likelihood function is a function of the probability respondent $i$ selects choice $j$ in the firsttier MNP, and subsequently accepts the offered bid for RCF beef in the second-tier probit. For each decision the choice probabilities are:

$$
\begin{aligned}
& \operatorname{Pr}\left(U_{i}^{*}=2\right)=\Phi_{2}\left(\frac{\theta_{2}^{\prime} X_{i}-\theta_{1}^{\prime} X_{i}}{\sqrt{2}}, \frac{\theta_{2}^{\prime} X_{i}-\theta_{3}^{\prime} X_{i}}{\sqrt{2}}, 0.5\right), \\
& \operatorname{Pr}\left(U_{i}^{*}=3\right)=\Phi_{2}\left(\frac{\theta_{3}^{\prime} x_{i}-\theta_{1}^{\prime} x_{i}}{\sqrt{2}}, \frac{\theta_{3}^{\prime} X_{i}-\theta_{2}^{\prime} X_{i}}{\sqrt{2}}, 0.5\right), \\
& \operatorname{Pr}\left(U_{i}^{*}=1\right)=1-\operatorname{Pr}\left(U_{i}^{*}=2\right)-\operatorname{Pr}\left(U_{i}^{*}=3\right), \\
& \operatorname{Pr}\left(\text { Accept }_{i}^{*}=1 \mid U_{i}^{*}=3\right)=\Phi_{2}\left(\frac{\theta_{3}^{\prime} X_{i}}{\sqrt{2}}, \beta_{0}+\beta_{p} \cdot \text { Bid }_{i}+Z_{i}^{\prime} \beta, \rho_{3 \eta}\right),
\end{aligned}
$$

where $\Phi_{2}$ is the bivariate standard normal c.d.f. The log-likelihood of the system is:

$$
\begin{aligned}
& \ln L(\gamma)=\sum_{i=1}^{N} \omega_{i} \cdot m_{i 1} \cdot \ln \operatorname{Pr}\left(U_{i}^{*}=1\right)+\sum_{i=1}^{N} \omega_{i} \cdot m_{i 2} \cdot \ln \operatorname{Pr}\left(U_{i}^{*}=2\right)+ \\
& \sum_{i=1}^{N} \omega_{i} \cdot m_{i 3} \cdot \ln \operatorname{Pr}\left(U_{i}^{*}=3\right)+ \\
& \sum_{\substack{i \in\left(U_{i}^{*}=3\right) \\
\text { Accept } \\
i}}^{N} \omega_{i} \cdot \ln \operatorname{Pr}\left(\text { Accept }_{i}^{*}=1 \mid U_{i}^{*}=3\right)+ \\
& \sum_{\substack{i \in\left(U_{i}^{*}=3\right) \\
\text { Accept }}=0}^{N} \omega_{i} \cdot \ln \left(1-\operatorname{Pr}\left(\text { Accept }_{i}^{*}=1\right)\right)
\end{aligned}
$$

with $m_{i j}=1$ when alternative $j$ is chosen (zero otherwise), $N$ is the number of observations in the sample, and a subset is used for the probit portion of the model of accepting the bid, where $i \in\left(U_{i}^{*}=3\right)$ and Accept $_{i}=1$. Sampling weights $\left(\omega_{i}\right)$ enter the likelihood function to adjust for the survey design. The log likelihood function was maximized using full information maximum likelihood (Roodman, 2011).

The marginal effects of continuous explanatory variables and discrete effects of binary explanatory variables are calculated by differentiating the probabilities in equations $7-10$ with 
respect to each covariate (Greene, 2003). Standard errors of the marginal effects are estimated using a weighted bootstrap procedure (Lambert et al., 2014).

\subsection{Monte Carlo simulation of willingness-to-pay for RCF beef}

Following Hanemann (1984), the estimate of the mean conditional WTP is calculated as the negative of the sum of the estimated intercept $\left(\beta_{0}\right)$ and parameters weighted by a vector of sample means $(\bar{Z})$ of $k$ respondent characteristics and divided by the parameter estimate of the bid, $\beta_{p}$ :

$$
\overline{W T P}_{C}=-\frac{\beta_{0}+\bar{Z}^{\prime} \beta}{\beta_{p}}
$$

The WTP measure in (12) assumes a linear utility function.

Sensitivity of the WTP estimates to the sampling variability of the estimated model parameters was conducted with a Monte Carlo analysis. The multinomial probit and the WTP estimates were assumed to be random variables. The mean unconditional WTP is calculated using (12) along with the probability of supporting and being willing to pay some premium from equation (8):

$$
\overline{W T P}_{U C}=-\Phi_{2}\left(\frac{\theta_{3}^{\prime} \bar{X}_{i}-\theta_{1}^{\prime} \bar{X}_{i}}{\sqrt{2}}, \frac{\theta_{3}^{\prime} \bar{X}_{i_{i}}-\theta_{2}^{\prime} \bar{X}_{i}}{\sqrt{2}}, 0.5\right) \cdot\left(\frac{\beta_{0}+\bar{Z}^{\prime} \beta}{\beta_{p}}\right) .
$$

The model parameter estimates were drawn from a multivariate normal distribution as:

$$
\tilde{\gamma}_{t}=\gamma+K \zeta_{t}
$$

where, $K$ is the lower triangular matrix of $\operatorname{cov}(\gamma)$ 's Cholesky decomposition, $\zeta$ is a $\sim N(0,1)$ random variable, $t$ indexes a Monte Carlo iteration, and $\tilde{\gamma}_{t}$ indicates a parameter vector drawn

during iteration $t$. We conduct the Monte Carlo sensitivities for dichotomous variables affecting WTP at the 5 percent level of significance.

\section{Covariates}


The bid amount $\left(\right.$ Bid $\left._{i}\right)$ for RCF-certified beef appears in the second-tier probit but not in the selection MNP (the $X$ set of covariates). All other explanatory variables are included in the MNP and probit portions of the model.

Explanatory variables include demographic characteristics such as age, income, gender, education, marital and household statuses, region of residence, and political affiliation (Table 1). Other explanatory variables include monthly household beef expenditures per capita, binary variables reflecting respondent belief in the influences of their choice on the design of GHG emission reduction programs for beef production ${ }^{4}$, and if the respondent had ever donated time or money to environmental organizations.

A series of 24 opinion variables (Table 2) were reduced to a set of indexes using factor analysis. Only factors with the running sum of the principle components equal to at least 50 percent of the sum total of the eigenvalues were retained (Johnson and Wichern 2002). Factor membership of the opinion variables was determined by inspecting the standardized factor loadings (Lambert et al., 2011). The factor score variables are included in the multinomial probit and probit portions of the model and include concerns about climate change, keeping food prices low, the need for environmental regulation, the quality of the food system, the food industry's share of the costs of reducing the environmental impact of food production, and buying organic/local foods.

\section{Results}

Respondents are, on average, 46.8 years old, have annual household income of $\$ 66,000$, spend \$20.07 per month per person on beef and live in 2.8 member households. Most of the

\footnotetext{
${ }^{4}$ The question regarding beliefs in whether survey responses would influence policy design was, "In your opinion, how likely are responses to this survey to influence the design of programs that reduce GHG emissions associated with beef production?" If the respondent answered "somewhat likely" or "very likely", the dummy variable was treated as a " 1 ", and " 0 " otherwise.
} 
respondents are female (53\%), married (52\%), and reside in metropolitan areas (84\%). A majority either attended some college or attained a bachelor's or higher degree (59\%). About 40\% identified themselves as Republican. According to the U.S. Census data, U.S. residents 18 years or older are 51\% female (U.S. Census Bureau, 2015), and have median annual household incomes of $\$ 51,939$. Census data also indicates that $45 \%$ of US residents have attended some college or obtained a college degree (U.S. Census Bureau, 2014a), and 85\% reside in metropolitan areas (U.S. Census Bureau, 2014b). Compared with the general U.S. population, respondents had higher annual household incomes and attained higher levels of education. The percentages of female and metropolitan residents are similar to the Census data.

\section{Factors}

Factor loadings and eigenvalues of the factors are reported in Table 2. From the 24 opinion variables, six common underlying themes emerged: Climate Change, Low Food Price, Government Regulation, Food System Quality, Industry Bear Costs, and Buy Organic and Local. Variables reflecting concerns about climate change loaded onto the factor Climate Change, while variables reflecting greater concerns about low food prices relative to other issues loaded onto Low Food Price. Concerns about greater need for environmental regulation loaded onto Government Regulation. Feelings of greater confidence in the food system loaded onto Food System Quality, while opinions about food processing and farmers bearing more of the costs of reducing the environmental impact of food production loaded onto Industry Bear Costs. Variables reflecting the desire to purchase local or purchase organic whenever possible loaded onto Buy Organic and Local.

Estimated model

Overall Model Fit 
A Wald statistic comparing the hypothesized model with a restricted mode (intercepts only) model is 320. With 61 degrees of freedom, we reject the null hypothesis $\beta_{k}=0 \forall k$ at the 99 percent confidence level (Table 3). The correlation term for the MNP equation $j=3$ and the bid acceptance equation is significant, indicating a negative correlation between error terms from the equation for being willing to pay more for RCF-certified beef in the multinomial probit and accepting the bid offered in the probit equation. The multinomial probit equations (columns 1 and 2, Table 3) correctly classify $80.52 \%$ of the responses for those supporting but not being willing to pay more and $61.27 \%$ and for those supporting and willing to pay more, respectively. The probit model (column 3, Table 3) correctly classifies $82.63 \%$ of the responses regarding whether the respondent would be willing to pay the stated premium.

Premium

Because only respondents expressing a WTP a premium for RCF-certified beef in the first tier of the model continued to the valuation question, the offered premium (or bid) for RCFcertified beef only appears in the probit model (column 3 in Table 4 and column 4, Table 4). The estimated coefficient on, and marginal effect of, the premium is negative. The marginal effect suggests that as the stated premium increases by one dollar, the probability of willingness to pay it decreases by 0.0011 . Hence, an increase in the premium of $\$ 100$ per household per year would result in an 11 percent decrease in the probability for respondents who indicated a WTP premium for RCF-certified beef in the first tier of the model of stating a WTP to pay the premium. Opinions

Coefficients for all of the factor scores are significant in at least one of the two MNP equations and two out of three marginal effects for the MNP are significant for all but one (Food System Quality) of the factor scores. While only one factor score has a significant coefficient in 
the WTP probit (Food System Quality), the marginal effect of each factor score is significant for WTP the specified premium for RCF-certified beef. In addition, the signs for the coefficients and marginal effects were intuitively consistent. Respondents who (i) were more concerned about climate change, (ii) more supportive of environmental regulation of the agricultural sector, and (iii) more likely to buy local and organic foods were all more likely to both support the RCF program and be willing to pay a premium for RCF-certified beef, as evidenced by positive coefficients in one of both of the MNP equations in Table 3 (columns 1 and 2) and positive marginal effects in columns 3 and 4 in Table 4. Concern about climate change is a logical antecedent to support for a reduced carbon labeling program and WTP a premium for low carbon labeled products. The positive association between belief in the need for environmental regulation of the agricultural sector and support for the RCF program suggests that the voluntary (as opposed to regulatory) nature of the labeling program was not an important distinction for respondents who support environmental regulation. Respondents who purchase organic and locally produced food products may be motivated by environmental, and possibly climaterelated, concerns. It is therefore unsurprising that these individuals were more likely to be supportive of the program and willing to pay a premium. The negative marginal effect for supporting but not being willing to pay a premium for RCF-certified beef suggests that organic and local food consumers are more willing to "put their money where their mouth is", a notparticularly surprising result given these individuals' purchasing patterns. However, it is interesting that the marginal effect of organic and local food consumption on willingness to pay the specified premium is lower in magnitude than the marginal effect of supporting and being willing to pay a premium. This difference is suggestive perhaps that when faced with the stated 
premium for RCF-certified beef, these consumers may be more likely to consider substituting organic and local foods to achieve the public benefits associated with RCF-certified beef.

It is difficult to hypothesize a priori the level of support for the RCF program among consumers who more strongly believe that the agricultural industry should bear more of the costs of reducing its environmental impact, but one might expect these respondents to pay more for RCF-certified beef. The positive coefficients on both MNP equations in Table 3 and the negative marginal effect on not supporting the RCF program in Table 4 suggests that these respondents are more likely to support the program. However, the positive coefficients on both MNP equations in Table 3 and the positive marginal effects in columns 2 and 4 of Table 4 provide mixed evidence on WTP for RCF-certified beef. An interpretation of this finding is that these respondents generally desire reductions in the environmental impact of agricultural production even if they believe that the agricultural industry should bear more of the costs of that improvement.

Respondents who more strongly believe in the importance of keeping food prices low relative to other social goals were less likely to support the RCF program (negative coefficients in both MNP equations in Table 3 and positive marginal effect in column 1 in Table 4) and less likely to be willing to pay a premium for RCF-certified beef (negative coefficient in column 2 in Table 3 and negative marginal effects in columns 3 and 4, Table 4). Respondents who trust the safety of the U.S. food supply and the availability of quality food were less likely to pay a premium for RCF-certified beef as evidenced by negative coefficients in columns 2 and 3 of Table 3 and a negative marginal effect in column 4 of Table 4.

Demographics 
While a number of the estimated coefficients on the demographics are significant (Table 3), few of the demographic variables have significant marginal effects (Table 4). Not surprisingly, higher household income translates into an increased likelihood of supporting the program and willingness to pay a premium for RCF-certified beef. For each $\$ 1,000$ increase in household income, respondents are 0.09 percent more likely to support the RCF program (column 1, Table 4) and 0.09 percent more likely to both support the program and be willing to pay a premium for RCF-certified beef (column 3, Table 4). Households spending more on beef are more likely to support RCF-certified beef. With each additional dollar of beef expenditures, the probability of supporting RCF-certified beef increases by 0.05 percent. Respondents who have attended or graduated from college are 11.17 percent are less likely to support the RCF program and unwilling to pay more for RCF-certified beef. Being married decreases the probability of supporting and willingness to pay more for RCF-certified beef by 0.70 percent. Northeasterners are 11.31 percent less likely to support RCF-certified beef. Individuals who have donated to environmental organizations are 17.46 percent more likely to be willing to pay the specified premium for RCF-certified beef.

A greater number of the demographic variables have significant coefficients in the MNP and probit models (Table 3). Given that the coefficient on WTP the specified premium for RCFcertified beef is not conditioned on responses in the MNP while the marginal effects are, these coefficients are perhaps of greater interest than the others. Of those respondents who support the program and are willing to pay a premium for RCF-certified beef, those who attended college and those who reside in a metropolitan area are less likely to be willing to pay the stated premium. Among those who are supporters of an RCF-certified beef, respondents who are married, Republican and financial supporters of environmental organizations are more likely to 
be willing to pay the specified premium (column 3, Table 3). Respondents who are more highly educated and who live in metropolitan areas are more likely aware of, and have access to, lowcarbon substitutes for beef. These individuals are less likely to be willing to pay a substantial premium for RCF-certified beef. It is not surprising that respondents who previously donated to environmental organizations also display a WTP a premium for RCF-certified beef. Republicans who are supportive of the program and willing to pay a premium might be less likely to substitute away from beef or attracted by the voluntary nature of the program. Consequentiality

Respondents who believed their responses to the survey would influence the design of GHG emission reduction programs for beef production were more likely to support the RCF program and more likely to pay a premium for RCF-certified beef. Belief that results from the survey may influence GHG policy for beef production positively influences support for RCFcertified beef by 7.64 percent and positively influences probability of supporting and being willing to pay more for it by 6.84 percent. This result, i.e., that support for a hypothetical "prosocial" program is higher among consumers who believed their participation in the contingent valuation experiment could influence policy, is consistent with Herriges et al., (2010) and Vossler and Watson (2013), but not Vossler et al., (2012), which found that WTP was inversely correlated with consequentiality.

Shown at the bottom of Table 4, the predicted probability of not supporting RCF-certified beef is 0.2269 , the probability of supporting the program but unwilling to pay more is 0.4657 . The estimated probability of supporting RCF-certified beef and being willing to pay more for it is 0.2482 . Among supporters, the predicted probability that the respondents will accept the 
premium given that they are a supporter is 0.6217 . Hence, the joint probability of supporting and being willing to pay the specified premium is 0.1543 .

WTP Estimates

Estimates of WTP are calculated using the model coefficients and equations (12) and (13) and distributions simulated in a Monte Carlo analysis. As seen in Figure 4, with a total of 202 observations, the mean of the individual conditional WTPs is $\$ 306$ (with a 95 percent confidence interval of [\$233, \$431]), which is about 51.60 percent of the average annual household beef expenditure of $\$ 593$ among those who support and would pay more for RCF-certified beef. If we calculate a WTP across all respondents (including non-supporters and those unwilling to pay a premium), then the value drops to $\$ 64$; this is just over 10 percent of the average household beef expenditure of $\$ 639$ among all respondents. The Monte Carlo analysis of WTP for RCFcertified beef was also conducted across donation to an environmental organization because the marginal effect for this binary variable was statistically significant in the probit portion of the model. The mean conditional WTP for RCF-certified beef among respondents who donated to an environmental organization is $\$ 365$, while the WTP among respondents who have not donated is $\$ 263$; over $\$ 100$ difference between the two groups. The mean unconditional WTP for RCFcertified beef among respondents who donated to an environmental organization is $\$ 102$, while the WTP among those who have not donated is $\$ 49$.

Respondents who chose "I do not support it and am not willing to pay any more for beef from producers participating in it" or "I do support it but am not willing to pay any more for beef from producers participating in it", or rejected the WTP bids offered to them were asked to explain why they made such choices. Their responses are categorized in Table 5. About 22.39 percent of those who said they did not support RCF-certified beef indicated it was because they 
could not afford to do so due to their limited budget or income; 16.99 percent did not believe in climate change; 13.51 percent objected to government intervention into the free markets; and 9.27 percent believed that the GHG emissions from the cattle industry was negligible. Of the respondents who supported but would not pay more, 54.90 percent indicated that they could not afford to do so or felt it would be too expensive. Of the respondents rejecting the WTP bids offered to them, 20.45 percent attributed it to income or budget constraints. Thus, the most common reason for either not supporting or being willing to pay for the RCF program offered by respondents involved a budget constraint, although a significant number were also either skeptical of climate change or government regulation. This finding is concordant with conclusions in previous studies (e.g. Tobler et al., 2012; Mäkiniemi and Vainio, 2014) and our $a$ priori hypothesis. Comparison of the means with t-tests across respondents stating a limited budget or income was the reason for not supporting or being willing to pay more for RCFcertified beef versus those citing other reasons reveals that respondents citing budget and income reasons had statistically lower incomes at the 95 percent confidence level.

\section{Conclusions}

Support for an RCF labeling program comes from consumers who are generally more concerned with public welfare issues such as climate change, the environment, local foods, or agricultural policies and government regulations. By showing their support for the hypothetical RCFcertified beef program or their WTP a premium for beef products with the RCF-certified beef label, consumers indicate their demand for beef products are responsive to beef cattle farmers using management practices that reduce GHG emissions. This finding is consistent with trends favoring niche markets for beef and other food products. It is likely that beef products that 
provide desired product attributes might receive greater market acceptance and generate higher revenues from higher price margins.

Respondents who are not supportive of the hypothetical program or unwilling to pay a premium for RCF-certified beef tend to have lower incomes, spend less on beef, are less concerned about climate change, place more importance on cheaper food, do not believe the cost of supporting environmental management should be borne by farmers and retailers, and do not believe that the choices made in this experiment will influence policy. Meanwhile, supporters of the hypothetical program are higher income earning, less price conscious consumers who are more concerned about the environment and believe in the "consequential effect" of their choices. Such consumers may tend to shop at organic, "green" or "healthy" food types of outlets, which indicates locations where low GHG emission beef products might be more marketable. Therefore, to promote marketing interests towards such beef products, it may be a good practice to target this demographic and supply more of the environment-friendly labeled beef products to this specific consumer group at organic food outlets. The finding that among supporters, those who were Republicans and those with less years of formal education were more willing to pay the specified premium, is somewhat surprising. However, possible explanations are that college graduates may be skeptical of the effectiveness of the program while Republicans may be enticed by the voluntary nature of the program.

The results from the bid question suggest that, among "supporters" who are interested in low GHG emission beef products, consumers who (i) are concerned about climate change, (ii) believe in the efficacy of governmental regulation of the food system, (iii) already seek out organic and local foods, (iii) are less certain about the quality of the current food system, and (iv) prefer supporting local food production and reducing the environmental impact of food 
production to keeping food prices lower are more likely to be willing to pay a premium for RCFcertified beef.

While there are consumers who are unwilling to pay for the hypothetical emissionreduction cattle grazing program, a large number of them may be limited by their income or food budget. Therefore, it is likely that some of these consumers might turn to support and purchase beef products of this type if the price premium is lowered. This condition might be achieved with either improvements in livestock grazing technologies, or cost subsidies from a third party to mitigate additional cost burdens for consumers and farmers. Future studies could provide insights on optimal pricing and welfare transfer mechanisms.

These results should be informative to industry and policymakers who are interested in initiating a prescribed grazing program such as the RCF-certified beef program. The finding that consumers are willing to pay additional price premiums for RCF-certified beef suggests a market-based mechanism could provide premiums to incent conversion to practices, such as prescribed grazing, that may help reduce GHG emissions from some beef production systems.

This study has several limitations. First, the sample is limited to respondents in beef consuming households. Thus, there is the possibility some individuals who might have been willing to consume beef if it had lower GHG emissions might have been excluded from the study. Second, even though "cheap talk" methods to remind respondents of their budgets were used, as well as use of an opt-out that allowed respondents to express support for the program without expressing a willingness to pay a premium, potential for upward bias in WTP estimates remains a possibility in stated preference studies. Third, this study provided one program alternative. Future research might provide choices between several program alternatives to reduce GHG emissions as part of the beef production process. Providing multiple alternatives 
could moderate overbidding (Shi, Gao, and Chen, 2014). For example, this study does not examine consumer preferences for beef from feedlot-raised or feedlot-finished cattle. Including these production processes in the choice set would have enabled comparison of consumer preferences for a wider variety of production processes. Finally, estimates of prescribed grazing program costs should be compared with anticipated program costs as a further course of research. 


\section{References}

Aoki, K., Akai, K., 2013. Do consumers select food products based on Carbon Dioxide emissions? Advances in Production Management Systems. Competitive Manufacturing for Innovative Products and Services 398, 345-352.

Bailey, R., Froggatt, A., Wellesley, L., 2014. Livestock - Climate Change's Forgotten Sector: Global Public Opinion on Meat and Dairy Consumption. The Royal Institute of International Affairs, Chatham House, London.

Blaylock, J.R, Blisard, W.N., 1992. U.S. cigarette consumption: the case of low-income women. Amer. J Agric. Econ. 74: 698-705.

Blamey, R., Bennett, J, Morrison, M., 1999. Yea-saying in contingent valuation surveys. Land Econ. 75(1) 126-141.

Briske, D., Derner, J., Milchunas, D., Tate, K., 2013. An evidence-based assessment of prescribed grazing practices. Conservation Benefits of Rangeland Practices: Assessment, Recommendations, and Knowledge Gaps. D. Briske, ed. Lawrence, KS: Allen Press,

Bunch, D., 1991. Estimability in the multinomial probit model. Trans. Res. Part B: Methodological 25 (1), 1-12.

Capper, J.L., 2012. Is the grass always greener? Comparing the environmental impact of conventional, natural and grass- fed beef production systems. Animals 2, 127-143.

Capper, J.L., 2011. The environmental impact of beef production in the United States: 1977 compared with 2007. J. of Animal Sci. 89(12), 4249-4261.

Chalmers, N., Revoredo-Giha, C., Shackley, S., 2014. How prices affect Scottish household demand for milk products and their low carbon alternatives? The EAAE 2014 Congress 'Agri-Food and Rural Innovations for Healthier Societies'. Ljubljana, Slovenia, 2014. 16.

Conant, R.T., Six, J., Paustian, K., 2003. Land use effects on soil carbon fractions in the southeastern United States. I. Management-intensive versus extensive grazing. Biol Fertil Soils 38, 386-392.

Conant, Richard T., Paustian, K. Elliott, E., 2001. Grassland management and conversion into grassland effects on soil carbon. Ecological Applications 11(2), 343-355.

Cottle, D., J. Nolan, Wiedermann, S. 2011. Ruminant enteric methane mitigation: a review. Animal Production Science 51, 491-514.

Cummings, R., Taylor, L., 1999. Unbiased value estimates for environmental goods: a cheap talk design for the contingent valuation method. Am. Econ. Rev. 89 (3), 649-665.

DeBoer, J., Schoesler, H., Boersema, J., 2013. Climate change and meat eating: An inconvenient couple? J. Environ. Psych., 1-8.

DeRamus, H.A., Clement, T.C. , Giampola, D.D, Dickison, P.C., 2003. Methane emissions of beef cattle on forages: Efficiency of grazing management systems. J. Environmental Quality 32(1), 269-277. 
Desjardins, R.L., Worth, D.E., Verge, X., Maxime, D. Dyer,J., Cerkowniak, D., 2012. Carbon footprint of beef cattle. Sustainability 4, 3279-3301.

Dick, M., da Silva, M.A., Dewes, H., 2015. Life cycle assessment of beef cattle production in two typical grassland systems of southern Brazil. J. Clean. Prod. 96:426-434.

Echeverría, R., Moreira, V., Sepúlveda, C., Wittwer C., 2014. Willingness to pay for carbon footprint on foods. British Food J. 116(2), 186-196.

Environmental Working Group. 2011. Meat Eater's Guide to Climate and Health. Available at: http://www.ewg.org/meateatersguide/. Last accessed November 9, 2015.

Follett, R.F, Reed, D.A, 2010. Soil carbon sequestration in grazing lands: societal benefits and policy implications. Rangeland Ecology and Management 63(1): 4-15.

Garnett, T. 2011. Where are the best opportunities for reducing greenhouse gas emissions in the food system (including the food chain)? Food Policy 36, S23-S32.

Goldberger, A.S. Econometric Theory. Wiley, New York.

Grebitus, C., B. Steiner, B., Veeman, M., 2013. Personal values and decision making: evidence from environmental footprint labeling in Canada. American Journal of Agricultural Economics 95(2), 397-403.

Greene, W. H., 2003. Econometric Analysis. Prentice Hall, Upper Saddle River, NJ.

Gurian-Sherman, D., 2011. Raising the steaks: global warming and pasture-raised beef production in the United States. Union of Concerned Scientists, Cambridge, MA.

Hanemann, M., 1984. Welfare evaluations in contingent valuation experiments with discrete choices. Am. J. Agri. Econ. 66 (3), 332-341.

Heller, M.C. Keoleian, G.A., 2015. Greenhouse gas emission estimates of US dietary choices and food loss. J. Industrial Ecology 19(3), 391-401.

Herriges, J., Kling, C., Liu, C., Tobias, J., 2010. What are the consequences of consequentiality? J. Environ. Econ. and Manag. 59 (1), 67-81.

Hibbs, A., Kahl, D. W., PytlikZillig, L., Champion, B., Abdel-Monem, T., Steffensmeier, T. R., Rice, C. W., Hubbard, K., 2014. Agricultural producer perceptions of climate change and climate education needs for the Central Great Plains. J Extension 52 (3), Article 3FEA2.

Jensen, K. L., Lambert, D. M., Clark, C. D., Caroline, H., English, B., Larson, J., Yu, T. E., Hellwinckel, C., 2015. .US. cattle producer willingness to adopt or expand prescribed grazing. J. Agri. and Appl. Econ., 213-242.

Johnson, R., Wichern, D., 2002. Applied Multivariate Statistical Analysis. Vol. 5. Prentice Hall, Upper Saddle River, NJ.

Jones, C.M., Kammen. D. M., 2011. Quantifying carbon footprint reduction opportunities for u.s. households and communities. Environ. Sci. \& Technology 45(9), 4088-4095.

Kamamura, W., 1989. The estimation of multinomial probit models: a new calibration algorithm. Transportation Sci. 23 (4), 253-265.

Kessler, A., Goddard, E., Parkins, J., 2013. Exploring factors that influence perceptions of using genomics for emission reductions in beef cattle. 2013 AAEA \& CAES Joint Annual Meeting, Washington DC. 
Kimura, A., Wada, Y., Kamada, A., Masuda, T., Okamoto, M., Goto, S., Tsuzuki, D., Cai, D., Oka, T., Dan, I., 2010. Interactive effects of carbon footprint information and its accessibility on value and subjective qualities of food products. Appetite 55 (2), 271-278.

Koistinen, L., Pouta, E., Heikkilä, J., Forsman-Hugg, S., Kotro, J., Mäkelä, J., Niva, M., 2013. The impact of fat content, production methods and carbon footprint information on consumer preferences for minced meat. Food Qual. and Pref. 29, 126-13.

Kortelainen, M., Raychaudhuri, J., Roussillon, B., 2015. Effects of carbon reduction labels: evidence from scanner data. Economic Inquiry. Forthcoming.

Lambert, D., Clark, C., Wilcox, M., Cho, S., 2011. Distance, density, local amenities, and suburban development preferences in a rapidly growing East Tennessee county. Agri. and Human Values 28 (4), 519-532.

Lambert, D., English, B., Harper, D., Larkin, S., Larson, J., Mooney, D., Roberts, R., Velandia, M., Reeves, J. 2014. Adoption and frequency of precision soil testing in cotton production. J. of Agric. and Resource Econ., 39(1):115-132.

Lanz, B., Wurlod, J., Panzone, L., Swanson, T., 2014. Clean substitutes and the effectiveness of carbon footprint labels vs. Pigouvian subsidies: Evidence from a field experiment. Research Paper 32, Centre for International Environmental Studies, The Graduate Institute of Geneva. Available online at: http://repository.graduateinstitute.ch/record/287985/files/CIES_RP_32.pdf. Last accessed November 10, 2015.

Liebig, M.A., Gross,J.R., Kronberg,S.L., Phillips,R.L., Hanson, J.D., 2010. Grazing management contributions to net global warming potential: a long-term evaluation in the Northern Great Plains. J. Environmental Quality. 39,799-809.

List, J., 2001. Do explicit warnings eliminate the hypothetical bias in elicitation procedures? evidence from field auctions for sports cards. Am. Econ. Rev. 91, 1498-1507.

List, J., Gallet, C., 2001. What experimental protocol influence disparities between actual and hypothetical stated values? Environ. and Res. Econ. 20 (3), 241-254.

Long, J.S. Freese, J., 2014. Regression models for categorical dependent variables using STATA. College Station, TX: STATA Press.

Loomis, J., 2013.2013 WAEA keynote address: strategies for overcoming hypothetical bias in stated preference surveys. J. Agr. Resource Econ. 39(1):34-46

Ma, Z., Coppock, D.L., 2012. Perceptions of Utah ranchers toward carbon sequestration: Policy implications for US rangelands. J Environ Manag 111 (30), 78-86.

Mäkiniemi, J., Vainio, A., 2014. Barriers to climate-friendly food choices among young adults in Finland. Appetite 74, 12-19.

Matsdotter, E., Elofsson, K., Arntyr, J., 2014. Got green milk? A field experimental trial of consumer demand for a climate label. Working Paper Series 2. Department Economics, Swedish University of Agricultural Sciences. 
McFadden, D., 1981. Econometric models of probabilistic choice, in: Manski C., McFadden, D. (Eds.), Structural analysis of discrete data with econometric applications. MIT Press, Cambridge, MA, pp. 198-272.

Morgan, J.A., Follett, R.F., Allen, Jr., L.H., Del Grosso, S.J., et al., 2010. Carbon sequestration in agricultural lands of the United States. Journal of Soil and Water Conservation 65 (1), $6 \mathrm{~A}-13 \mathrm{~A}$.

Nickerson, C., Ebel, R., Borchers, A., Carriazo, F., 2011. Major Uses of Land in the United States, 2007. U.S. Department of Agriculture, Economic Research, Washington, DC.

Niles, M. T., Lubell, M., Haden, V. R., 2013. Perceptions and responses to climate policy risks among California farmers. Global Environ. Change 23, 1752-1760.

Nishino, N., Akai, K., Tamura, H., 2014. Product Differentiation and Consumer's Purchase Decision-making under Carbon Footprint Scheme. Product Services Systems and Value Creation. Proceedings of the 6th CIRP Conference on Industrial Product-Service Systems $16,116-121$.

Oates, L.G., Jackson, R.D. 2014. Livestock Management Strategy Affects Net Ecosystem Carbon Balance of Subhumid Pasture. Rangeland Ecol. \& Mgmt. 67(1), 19-29.

Onozaka, Y, W. Hu, Thilmany, D., 2015. Can eco-labels reduce carbon emissions? market-wide analysis of carbon labeling and locally grown fresh apples. Renewable Agriculture and Food Systems. Forthcoming.

Onozaka, Y., Thilmany McFadden, D., 2011. Does local labeling complement or compete with other sustainable labels? a conjoint analysis of direct and joint values for fresh produce claims. Amer. J. Agric. Econ. 93(3), 693-706.

Panzone, L., G Perino, T. Swanson, Leung, D., 2011. Testing for the best instrument to generate sustainable food consumption. J. Food Syst. Dynamics 2(3), 237-252.

Pelletier, N., R. Pirog, Rasmussen, R. 2010. Comparative life cycle environmental impacts of three beef production strategies in the Upper Midwestern United States. Agricultural Systems 103(6), 380-389.

Perino, G. L.A. Panzone, Swanson, T. 2014. Motivation crowding in real consumption decisions: who is messing with my groceries? Economic Inquiry, 52(2), 592-607.

Phetteplace, H.W., D.E. Johnson, Seidl, A.F., 2001. Greenhouse gas emissions from simulated beef and dairy livestock systems in the United States. Nutrient Cycling in Agroecosystems 60, 99-102.

Roodman, D., 2011. Fitting fully observed recursive mixed-process models with cmp. The Stata J. 11, 159-206.

Saunders, C., Guenther, M. Kaye-Blake, W., Miller, S., Tait, P., 2010. Consumer attitudes towards sustainability attributes on food labels. 2010 NZARES Conference, Nelson, New Zealand, pp. 1-17.

Sharp, A. Wheeler, M., 2013. Reducing householders' grocery carbon emissions: Carbon literacy and carbon label preferences. Australiasian Marketing Journal 21, 240-249. 
Shi, L., Gao, Z, Chin, X., 2014. The cross-price effect on willingness-to-pay estimates in openended contingent valuation. Food Policy, 46, 31-21.

Spaargaren, G., van Koppen,C., Janssen,A., Hendriksen,A., Kolfschoten,C., 2013. Consumer responses to the carbon labelling of food: a real life experiment in a canteen practice. Sociologia Ruralis 53(4),432-453.

Train, K. 2002. Discrete choice methods with simulation. Cambridge: Cambridge University Press. 113-114.

Tobler, C., Visschers, V., Siegrist, M., 2012. Addressing climate change: Determinants of consumers' willingness to act. J. Environ. Psychology 32, 197-207.

Undersander, D., Albert,B., Cosgrove,D., Johnson, D., and Peterson, P. 2002. Pastures for profit: a guide to rotational grazing. University of Wisconsin Cooperative Extension Report A3529.

U.S. Census Bureau, 2015. 2009-2013 5-Year American Community Survey. http://factfinder.census.gov/faces/tableservices/jsf/pages/productview.xhtml?pid=ACS_1 3_5YR_DP05\&src=pt (accessed May 27, 2015), Washington DC.

U.S. Census Bureau, 2014a. Educational Attainment in the United States: 2013 - Detailed Tables. http://www.census.gov/hhes/socdemo/education/data/cps/2014/tables.html (accessed May 27, 2015), Washingtong DC.

U.S. Census Bureau, 2014b. Population and Housing Unit Estimates. http://www.census.gov/popest/ (accessed May 27, 2015). Washington, DC.

U.S. Department of Agricuture, Natural Resource Conservation Service (USDA/NRCS), 2010. Natural Resources Conservation Service Conservation Practice Standard, Code 528 Prescribed Grazing. Washington, DC, 2010. http://www.nrcs.usda.gov/Internet/FSE_DOCUMENTS/nrcs143_025729.pdf

U. S. Department of Agriculture, Natural Resource Conservation Service (USDA/NRCS). Environmental Incentives Program (EQIP). Internet site: http://www.nrcs.usda.gov/Internet/NRCS_RCA/reports/fb08_cp_eqip.html. (Accessed Dec. 5, 2013).

U.S. Environmental Protection Agency (USEPA), 2015. Inventory of U.S. Greenhouse Gas Emissions and Sinks: 1990-2013. Washington, DC.

Van Loo, E. J., Caputo, V. Nayga Jr., R. M., Verbekem, W., 2014. Consumers' valuation of sustainability labels on meat. Food Policy 49, 137-150.

Vanclay, J., Shortiss, J., Aulsebrook, S., Gillespie, A., Howell, B., Johanni, R., Maher, M., Mitchell, K., Stewart, M., Yates, J., 2011. Customer response to carbon labelling of groceries. J. Consumer Policy 34 (1), 153-160.

Vossler, C., Watson, S., 2013. Understanding the consequences of consequentiality: Testing the validity of stated preferences in the field. J. Econ. Behavior \& Organiz. 86, 137-147.

Vossler, C., Doyon, M., Rondeau, D., 2012. Truth in consequentiality: theory and field evidence on discrete choice experiments. Am. Econ. J.: Microeconomics 4 (4), 145-171. 
Wienhold, B.J., Hendrickson, J.R., Karn, J.F., 2001. Pasture management influences on soil properties in the northern Great Plains. J. of Soil \& Water Conservation 56, $27-31$. 


\section{Appendix: derivation of the error covariance matrix in Equation 6}

Derivation of the covariance matrix in equation 6 follows. The covariance matrix of $\left(\xi_{i 1}, \xi_{i 2}, \xi_{i 3}, \eta_{i}\right)$ is,

$$
\Omega=\left[\begin{array}{cccc}
1 & 0 & 0 & 0 \\
0 & 1 & 0 & 0 \\
0 & 0 & 1 & \sigma_{3 \eta} \\
0 & 0 & \sigma_{3 \eta} & 1
\end{array}\right],
$$

where the diagonal $[1: 3,1: 3]$ elements correspond with the variance terms of the multinomial probit (MNP) portion of the model, and the [4:4] element the variance term of the willingness to pay equation. The $[3,4]$ element is the covariance between the $\left(\xi_{i 3}, \eta_{i}\right)$ errors.

The covariance matrix in A1 is identified by imposing the independence of irrelevant alternatives (IIA) assumption and omitting one of the choice categories with the transformation matrix

$$
M=\left[\begin{array}{cccc}
-1 & 1 & 0 & 0 \\
-1 & 0 & 1 & 0 \\
0 & 0 & 0 & 1
\end{array}\right]
$$

such that choice 1 is the reference category. The modified covariance matrix is,

$$
\widetilde{\Omega}=M \Omega M^{\prime}=\left[\begin{array}{ccc}
2 & 1 & 0 \\
1 & 2 & \sigma_{3 \eta} \\
0 & \sigma_{3 \eta} & 1
\end{array}\right],
$$

with $\operatorname{cov}\left(\xi_{i 3}^{*}, \eta_{i}\right)=\sigma_{3 \eta}=\sqrt{2} \cdot \rho_{3 \eta}$. Note that when $\rho_{3 \eta}=0$, the [1:2,1:2] elements of $\widetilde{\Omega}$ correspond with the covariance matrix of the standard MNP under the IIA assumption (Long and Freese, 2014). 


\section{Greenhouse Gas Emissions and Beef Production}

- Gases that trap heat in the atmosphere are called greenhouse gases (GHG).

- GHG have been linked with global climate change.

- Beef production accounts for about $2.2 \%$ of all U.S. GHG emissions.

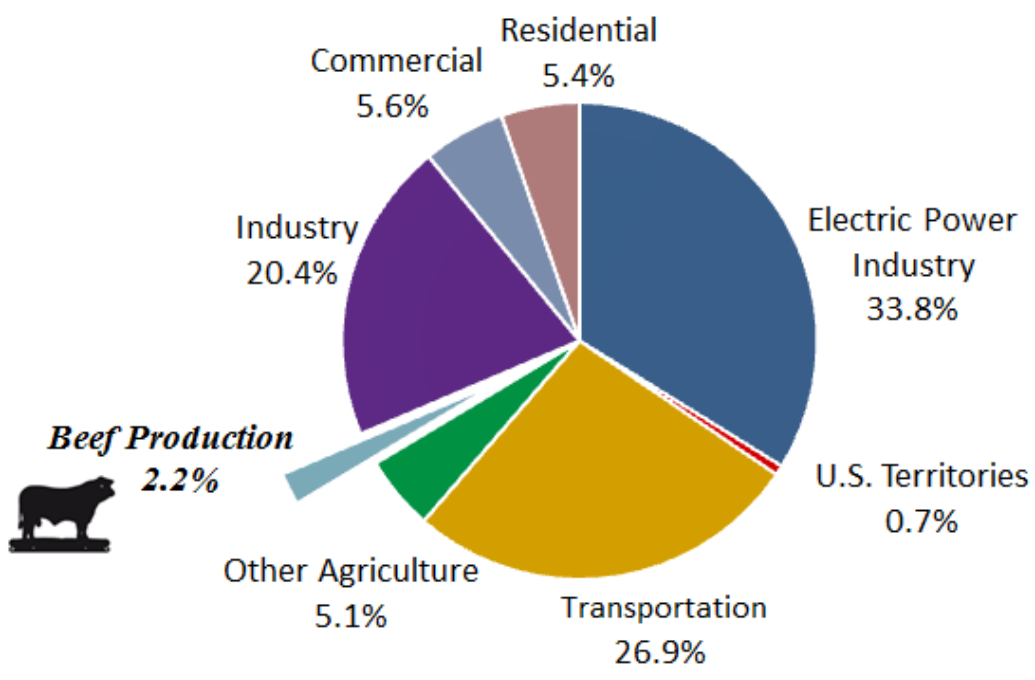

U.S. Greenhouse Gas Emissions by Economic Sector

Figure 1. Information Screen Provided in Survey to Study Participants Regarding U.S. Beef Production and GHG Emissions 


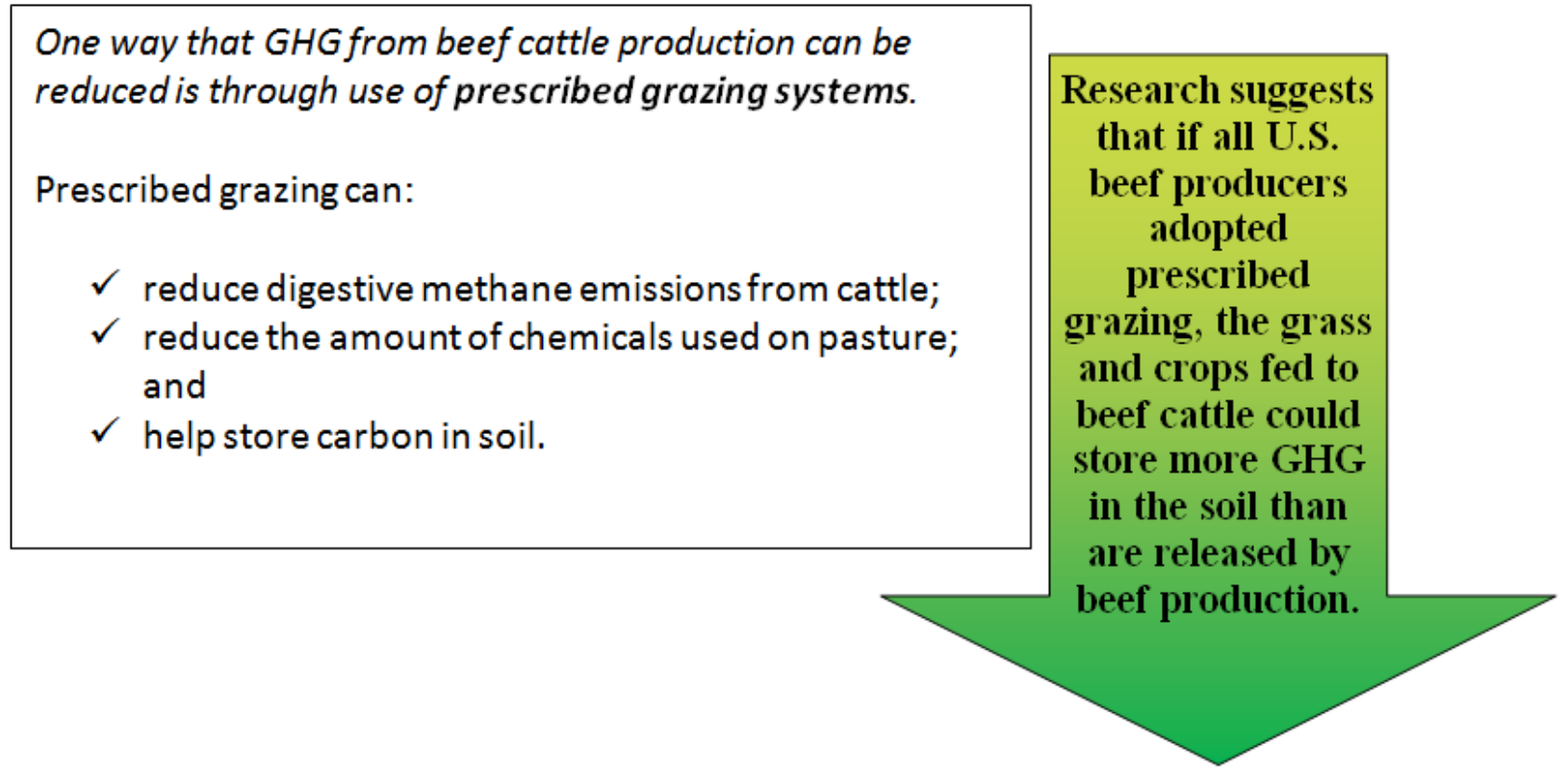

Figure 2. Information Screen Provided in Survey to Study Participants Regarding Prescribed Grazing 


\section{Promoting Prescribed Grazing}

Suppose there was a program providing payments to farmers who adopt prescribed grazing practices. The payments would cover part of the costs of adopting prescribed grazing. The farmers would also receive an annual payment for up to 10 years if they continue to practice prescribed grazing. An independent third party would verify that the farmers had adopted and continued to use prescribed grazing practices. If all beef farmers adopted prescribed grazing practices, total U.S. greenhouse gas emissions could be reduced by as much as $2 \%$.

\section{Raised Carbon Friendly}

Funding for this program would come from beef consumers who are willing to pay additional amounts for beef each year to help offset the costs to adopt prescribed grazing by farmers.

Beef from farms using prescribed grazing practices would be certified and identified by a label on the product, such as the one shown below.

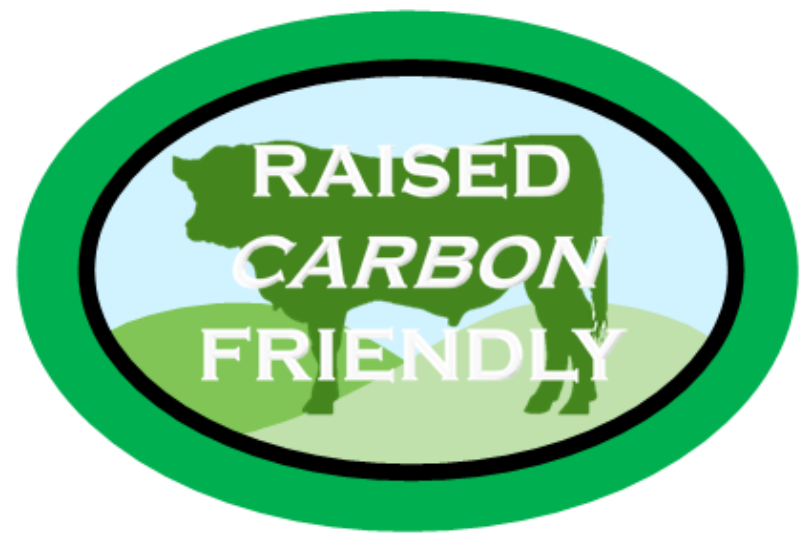

Figure 3. Information Screen Provided in Survey to Study Participants Regarding "Raised Carbon Friendly" Program 

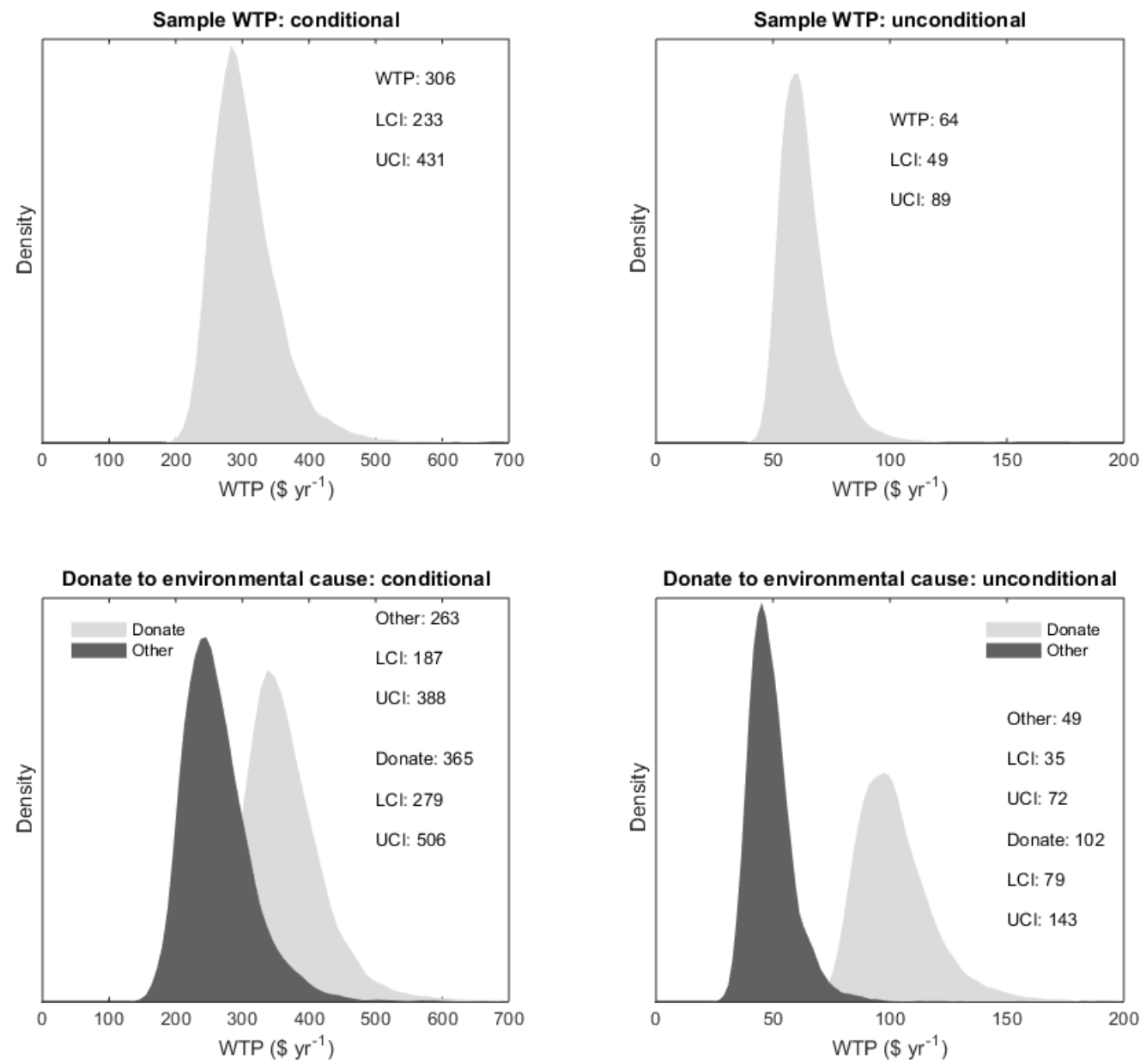

Figure 4. Monte Carlo simulation of conditional and unconditional WTP for RCF-Certified beef. $^{\text {a }}$

a. LCI, UCI are lower and upper $95 \%$ confidence intervals. 
Table 1. Descriptions and Sample Means for Variables Used in Modeling Support and Willingness to Pay for Raised Carbon Friendly Certified Beef

\begin{tabular}{|c|c|c|c|c|c|c|}
\hline \multirow[b]{2}{*}{ Variable } & \multirow[b]{2}{*}{ Description } & \multicolumn{4}{|c|}{$\begin{array}{c}\text { Sample Means } \\
\text { Support for } R C F \text {-Certified Beef }\end{array}$} & \multirow[b]{2}{*}{$\begin{array}{l}\text { WTP } \\
\text { Specified } \\
\text { Premium } \\
\text { for RCF- } \\
\text { Certified } \\
\text { Beef } \\
(\mathrm{N}=202)\end{array}$} \\
\hline & & $\begin{array}{l}\text { Overall } \\
(\mathrm{N}=806)\end{array}$ & $\begin{array}{l}\text { Does Not } \\
\text { Support } \\
(\mathrm{N}=233) \\
\end{array}$ & $\begin{array}{l}\text { Supports } \\
\text { but Will } \\
\text { Not Pay } \\
\text { More } \\
(\mathrm{N}=371)\end{array}$ & $\begin{array}{l}\text { Supports } \\
\text { and Will } \\
\text { Pay } \\
\text { More } \\
(\mathrm{N}=202)\end{array}$ & \\
\hline $\begin{array}{l}\text { Support for RCF- } \\
\text { Certified Beef }\end{array}$ & $\begin{array}{l}\text { 1= Does not support RCF-Certified } \\
\text { Beef, } 2=\text { Supports but will not pay more } \\
\text { for RCF-Certified Beef, } 3=\text { Supports and } \\
\text { will pay more for RCF-Certified Beef }\end{array}$ & 1.99 & 1 & 2 & 3 & \\
\hline $\begin{array}{l}\text { Willingness to Pay } \\
\text { Specified Premium } \\
\text { for RCF-Certified } \\
\text { Beef }\end{array}$ & $\begin{array}{l}1=\text { Will pay specified premium for } \\
\text { RCF-Certified Beef, } 0=\text { Will not pay } \\
\text { specified premium for RCF-Certified } \\
\text { Beef }\end{array}$ & & & & & 0.70 \\
\hline Premium & $\begin{array}{l}\text { Premium for RCF-Certified Beef } \\
\text { presented to respondents (\$/year) }\end{array}$ & & & & & 128.44 \\
\hline Age & Respondent age in years & 46.82 & 50.27 & 46.18 & 44.43 & “" \\
\hline $\begin{array}{l}\text { Household Income } \\
(\$ 1,000)\end{array}$ & Annual household income in $\$ 1,000$ & 66.21 & 63.61 & 64.90 & 71.41 & “" \\
\hline Beef Expenditures & $\begin{array}{l}\text { Monthly household beef expenditure per } \\
\text { capita (\$), calculated using categorical } \\
\text { midpoints: less than } \$ 9, \$ 9 \text { to } \$ 17, \$ 18 \\
\text { to } \$ 26, \$ 27 \text { to } \$ 35 \text {, more than } \$ 35\end{array}$ & 20.07 & 19.74 & 20.35 & 19.90 & “" \\
\hline College & $\begin{array}{l}1 \text { if attended college or obtained a } \\
\text { college degree (no college is the base } \\
\text { case) }\end{array}$ & 0.59 & 0.59 & 0.51 & 0.73 & “ \\
\hline Female & 1 if female, 0 otherwise & 0.53 & 0.53 & 0.54 & 0.53 & “" \\
\hline Married & 1 if married, 0 otherwise & 0.52 & 0.58 & 0.51 & 0.48 & “" \\
\hline Household Size & Number of members of household & 2.82 & 2.78 & 2.93 & 2.65 & “ ” \\
\hline Metropolitan Area & $\begin{array}{l}1 \text { if reside in metropolitan area, } 0 \\
\text { otherwise }\end{array}$ & 0.84 & 0.76 & 0.86 & 0.89 & “ \\
\hline Northeast & $\begin{array}{l}1 \text { if reside in Northeast, } 0 \text { otherwise } \\
\text { (South is the base case) }\end{array}$ & 0.16 & 0.19 & 0.14 & 0.17 & “ ” \\
\hline Midwest & $\begin{array}{l}1 \text { if reside in Midwest, } 0 \text { otherwise } \\
\text { (South is the base case) }\end{array}$ & 0.23 & 0.17 & 0.25 & 0.24 & “" \\
\hline West & $\begin{array}{l}1 \text { if reside in West, } 0 \text { otherwise (South is } \\
\text { the base case) }\end{array}$ & 0.22 & 0.28 & 0.20 & 0.21 & “ " \\
\hline Republican & 1 if Republican, 0 otherwise & 0.40 & 0.59 & 0.38 & 0.23 & “" \\
\hline
\end{tabular}


Climate Change

Factor score on attitudes towards climate change

Low Food Price Factor score on attitudes towards importance of low food prices

Government Factor score on attitudes toward

Regulation Needed government regulation and policies

Food System

Quality

Industry Bear

Costs

Buy Organic and

Local

Factor score on attitudes toward quality of the food system

Factor score on attitudes toward industry bearing cost-burden for GHG mitigation

Donated to Envir. 1 if respondent has ever donated time or Organiz

Influence $G H G$ Beef Policy money to environmental organizations, 0 otherwise

1 if respondents consider that their choices are somewhat or very likely to influence the design of GHG emission reduction programs for beef production, 0 otherwise

$\begin{array}{lllll}0.04 & -0.56 & 0.13 & 0.47 & \text { “ } \\ 0.05 & 0.26 & 0.12 & -0.30 & \text { “ }, \\ 0.07 & -0.41 & 0.17 & 0.40 & \text { “ } \\ 0.00 & 0.05 & 0.01 & -0.05 & \text { “ } \\ 0.03 & -0.29 & 0.12 & 0.19 & \text { “ }, \\ 0.01 & 0.00 & -0.16 & 0.32 & \\ 0.24 & 0.14 & 0.21 & 0.42 & \\ & & & & \\ 0.49 & 0.28 & 0.51 & 0.65\end{array}$


Table 2. Factor Analysis: Respondent Attitudes Toward the Environment, Food, Agricultural Production, and the Government ${ }^{\mathrm{a}}$

\begin{tabular}{|c|c|c|c|c|c|c|c|}
\hline Attitudinal Statements & $\begin{array}{l}\text { Climate } \\
\text { Change }\end{array}$ & $\begin{array}{l}\text { Low Food } \\
\text { Price }\end{array}$ & $\begin{array}{l}\text { Govern- } \\
\text { ment } \\
\text { Regulation } \\
\text { Needed }\end{array}$ & $\begin{array}{l}\text { Food System } \\
\text { Quality }\end{array}$ & $\begin{array}{l}\text { Industry } \\
\text { Bear } \\
\text { Costs }\end{array}$ & $\begin{array}{l}\text { Buy } \\
\text { Organic } \\
\text { and Local }\end{array}$ & $\begin{array}{l}\text { Uniqu- } \\
\text { eness }\end{array}$ \\
\hline $\begin{array}{l}\text { Good quality food is affordable for most } \\
\text { people in the U.S. }\end{array}$ & -0.22 & 0.04 & -0.02 & 0.71 & 0.15 & -0.05 & -0.07 \\
\hline The U.S. food supply is safe and reliable. & -0.15 & 0.04 & 0.17 & 0.79 & -0.05 & -0.11 & -0.08 \\
\hline $\begin{array}{l}\text { Governmental regulation of agriculture is } \\
\text { necessary to ensure a safe, reliable, and } \\
\text { affordable food supply. }\end{array}$ & 0.35 & -0.10 & 0.58 & 0.36 & 0.04 & -0.07 & 0.12 \\
\hline $\begin{array}{l}\text { Government payments to farmers promote } \\
\text { a safe, reliable, and affordable food } \\
\text { supply. }\end{array}$ & 0.17 & -0.05 & 0.81 & 0.20 & -0.08 & 0.00 & 0.12 \\
\hline $\begin{array}{l}\text { Keeping food prices low is more important } \\
\text { than reducing the environmental impact of } \\
\text { food production. }\end{array}$ & -0.35 & 0.50 & -0.12 & 0.22 & -0.28 & -0.16 & 0.20 \\
\hline $\begin{array}{l}\text { Keeping food prices low is more important } \\
\text { than ensuring that farmers receive a fair } \\
\text { income. }\end{array}$ & -0.13 & 0.77 & -0.07 & 0.07 & 0.18 & -0.01 & -0.07 \\
\hline $\begin{array}{l}\text { Keeping food prices low is more important } \\
\text { than providing safe, healthy and nutritious } \\
\text { food choices. }\end{array}$ & -0.25 & 0.74 & 0.00 & -0.04 & 0.05 & -0.04 & 0.07 \\
\hline $\begin{array}{l}\text { Keeping food prices low is more important } \\
\text { than supporting my local economy. }\end{array}$ & -0.15 & 0.75 & 0.02 & 0.05 & -0.02 & -0.18 & -0.02 \\
\hline $\begin{array}{l}\text { Government regulation of agricultural } \\
\text { production should be increased to reduce } \\
\text { agriculture's impact on the environment. }\end{array}$ & 0.42 & 0.00 & 0.60 & -0.12 & 0.36 & 0.12 & -0.07 \\
\hline $\begin{array}{l}\text { Farmers should bear more of the costs of } \\
\text { reducing the environmental impact of crop } \\
\text { and livestock production. }\end{array}$ & 0.09 & 0.17 & 0.06 & 0.06 & 0.84 & -0.01 & 0.08 \\
\hline $\begin{array}{l}\text { Food processors, distributors and retailers } \\
\text { should bear more of the costs of reducing } \\
\text { the environmental impact of agriculture. }\end{array}$ & 0.31 & -0.14 & 0.04 & 0.04 & 0.65 & 0.01 & 0.16 \\
\hline $\begin{array}{l}\text { Taxpayers should bear more of the costs of } \\
\text { reducing the environmental impact of } \\
\text { agricultural production. }\end{array}$ & 0.14 & 0.08 & 0.56 & -0.24 & 0.35 & 0.22 & -0.12 \\
\hline $\begin{array}{l}\text { I buy organic food products whenever they } \\
\text { are available. }\end{array}$ & 0.12 & -0.04 & 0.10 & -0.21 & 0.10 & 0.75 & -0.24 \\
\hline $\begin{array}{l}\text { My personal actions have a negligible } \\
\text { impact on the environment. }\end{array}$ & 0.04 & 0.36 & -0.22 & 0.20 & -0.08 & 0.28 & 0.07 \\
\hline $\begin{array}{l}\text { Science and technology will solve } \\
\text { environmental problems. }\end{array}$ & 0.03 & 0.35 & 0.11 & 0.47 & 0.01 & 0.12 & 0.05 \\
\hline $\begin{array}{l}\text { We have a responsibility to future } \\
\text { generations to protect the environment. }\end{array}$ & 0.48 & -0.36 & -0.03 & 0.28 & 0.06 & 0.27 & 0.00 \\
\hline
\end{tabular}


I don't have enough knowledge to make well-informed decisions on environmental 0.0 issues.

I buy locally produced foods whenever I can.

0.1

0.02

0.07

$-0.08$

$0.11-0.03$

0.89

Global climate change is occurring.

$\mathbf{0 . 8 7}-0.10$

$-0.01$

0.08

$-0.12 \quad \mathbf{0 . 6 6}$

0.30

Human activity is contributing to global climate change.

0.85

$-0.12$

0.10

0.00

$\begin{array}{lll}0.05 & 0.05 & 0.00\end{array}$

There is no urgent need to take measures to slow climate change.

$\mathbf{- 0 . 6 1} \quad 0.20$

$0.15 \quad-0.07$

$0.12-0.01$

0.04

Global climate change will cause problems in many parts of the world.

$\begin{array}{lllllll}\mathbf{0 . 8 9} & -0.10 & 0.08 & -0.06 & 0.04 & 0.06 & 0.03\end{array}$

Global climate change will affect food production.

$\begin{array}{lllllll}\mathbf{0 . 8 7} & -0.11 & 0.08 & -0.06 & 0.04 & 0.07 & 0.03\end{array}$

Global climate change will eventually cause me personal harm.

$\begin{array}{lllllll}\mathbf{0 . 7 0} & -0.03 & 0.23 & -0.20 & 0.13 & 0.15 & 0.10\end{array}$

a. Factor loadings larger than 0.5 in bold. 
Table 3. Estimated Model of Support and WTP a Premium for Raised Carbon Friendly Certified Beef $^{\mathrm{a}, \mathrm{b}}$

\begin{tabular}{|c|c|c|c|}
\hline Variable & $\begin{array}{c}\text { Column } 1 \\
\text { Supports but Will } \\
\text { Not Pay More for } \\
\text { RCF-Certified } \\
\text { Beef }\end{array}$ & $\begin{array}{l}\text { Column } 2 \\
\text { Supports and Will } \\
\text { Pay More for } \\
\text { RCF-Certified } \\
\text { Beef }\end{array}$ & $\begin{array}{c}\text { Column } 3 \\
\text { Will Pay Specified } \\
\text { Premium for } \\
\text { RCF-Certified } \\
\text { Beef }\end{array}$ \\
\hline Premium (\$/year) & & & $-0.0075^{* * *}$ \\
\hline Age (years) & -0.0070 & $-0.0145^{* *}$ & 0.0022 \\
\hline Household Income $(\$ 1,000)$ & 0.0038 & $0.0076^{* *}$ & -0.0008 \\
\hline Beef Expenditures (\$/yr) & 0.0040 & -0.0060 & -0.0072 \\
\hline College $(1=$ yes $)$ & $-0.4230^{* *}$ & -0.0096 & $-0.5107^{*}$ \\
\hline Female $(1=$ yes $)$ & -0.1128 & $-0.4460^{* *}$ & 0.1563 \\
\hline Married $(1=$ yes $)$ & -0.0868 & -0.1040 & $0.4210^{*}$ \\
\hline Household Size (count) & 0.0634 & -0.0012 & 0.1969 \\
\hline Metropolitan (1 = yes) & 0.3579 & 0.3477 & $-0.6441^{*}$ \\
\hline Northeast $(1=$ yes $)$ & $-0.6732^{* *}$ & -0.4985 & -0.3261 \\
\hline Midwest $(1=$ yes $)$ & 0.1557 & 0.0797 & 0.1807 \\
\hline West $(1=$ yes $)$ & $-0.4865^{*}$ & -0.3722 & 0.3492 \\
\hline Republican $(1=$ yes $)$ & 0.0418 & -0.3039 & $0.7154^{* *}$ \\
\hline Climate Change (factor) & $0.6809^{* * * *}$ & $0.9629^{* * *}$ & -0.0232 \\
\hline Low Food Price (factor) & $-0.2412^{* *}$ & $-0.6605^{* * * *}$ & -0.1844 \\
\hline Government Regulation (factor) & $0.5372^{* * *}$ & $0.8495^{* * *}$ & -0.0579 \\
\hline Food System Quality (factor) & -0.0602 & $-0.1885^{*}$ & $-0.2838^{* *}$ \\
\hline Industry Bear Costs (factor) & $0.3769^{* * *}$ & $0.4135^{* * *}$ & 0.1108 \\
\hline Buy Organic and Local (factor) & -0.0992 & $0.2660^{* * *}$ & 0.1532 \\
\hline Donated Envir. Organ. $(1=$ yes $)$ & 0.1795 & $0.5248^{* *}$ & $0.7590^{* *}$ \\
\hline Influence Policy $(1=$ yes $)$ & $0.3572^{*}$ & $0.6394^{* * *}$ & -0.3522 \\
\hline Constant & 0.5732 & 0.0459 & $2.0584^{* * *}$ \\
\hline$\rho_{3, \eta}$ & & $-0.6211^{* * * *}$ & \\
\hline Percent correctly predicted & $80.52 \%$ & $61.27 \%$ & $82.63 \%$ \\
\hline Log likelihood & & -701 & \\
\hline Wald test, $H 0: \beta=0,61 \mathrm{df}$ & & $320 * * *$ & \\
\hline Observations & & 806 & \\
\hline
\end{tabular}

a. $* * *$ indicates significance at $\alpha=.01, * *$ at $\alpha=.05$, and $*$ at $\alpha=.10$.

b. Does Not Support RCF-Certified Beef is constrained. 
Table 4. Marginal Effects of Consumer Demographics and Attitudes on Support and WTP a Premium for Raised Carbon Friendly (RCF) Certified Beef ${ }^{a, b, c}$

\begin{tabular}{|c|c|c|c|c|}
\hline Variable & $\begin{array}{c}\text { Column } 1 \\
\\
\text { Does Not } \\
\text { Support } \\
\text { RCF- } \\
\text { Certified } \\
\text { Beef } \\
\end{array}$ & $\begin{array}{c}\text { Supports but } \\
\text { Will Not Pay } \\
\text { More for } \\
\text { RCF-Certified } \\
\text { Beef }\end{array}$ & $\begin{array}{c}\text { Column } 3 \\
\text { Supports } \\
\text { and Will } \\
\text { Pay More } \\
\text { for RCF- } \\
\text { Certified } \\
\text { Beef }\end{array}$ & $\begin{array}{l}\text { Column } 4 \\
\text { Will Pay } \\
\text { Specified } \\
\text { Premium } \\
\text { for RCF- } \\
\text { Certified } \\
\text { Beef }\end{array}$ \\
\hline Premium (\$/year) & & & & $-0.0011 * *$ \\
\hline Age (years) & 0.0016 & 0.0001 & -0.0017 & -0.0016 \\
\hline Household Income $(\$ 1,000)$ & $-0.0009 *$ & 0.0000 & $0.0009 *$ & 0.0009 \\
\hline Beef Expenditures (\$/yr) & $-0.0005 * *$ & 0.0019 & -0.0016 & -0.0018 \\
\hline College $(1=$ yes $)$ & 0.0556 & $-0.1117 * *$ & 0.0571 & -0.0665 \\
\hline Female $(1=$ yes $)$ & 0.0345 & 0.0314 & -0.0652 & -0.0353 \\
\hline Married $(1=$ yes $)$ & 0.0166 & -0.0087 & $-0.0070 *$ & 0.0449 \\
\hline Household Size (count) & -0.0096 & 0.0169 & -0.0089 & 0.0277 \\
\hline Metropolitan (1 = yes) & -0.0625 & 0.0486 & 0.0150 & -0.0257 \\
\hline Northeast $(1=$ yes $)$ & $0.1131 * *$ & -0.1120 & -0.0023 & -0.1168 \\
\hline Midwest $(1=$ yes $)$ & -0.0243 & 0.0302 & -0.0071 & 0.0353 \\
\hline West $(1=$ yes $)$ & 0.0788 & -0.0790 & -0.0026 & -0.0067 \\
\hline Republican (1 = yes $)$ & 0.0120 & 0.0522 & -0.0601 & 0.0420 \\
\hline Climate Change (factor) & $-0.1389 * *$ & 0.0479 & $0.0811 * *$ & $0.1233 * *$ \\
\hline Low Food Price (factor) & $0.0618 * *$ & 0.0267 & $-0.0865 * *$ & $-0.1129 * *$ \\
\hline Government Regulation (factor) & $-0.1151 * *$ & 0.0255 & $0.0802 * *$ & $0.1034 * *$ \\
\hline Food System Quality (factor) & 0.0181 & 0.0099 & -0.0259 & $-0.0649 * *$ \\
\hline Industry Bear Costs (factor) & $-0.0727 * *$ & $0.0429 * *$ & 0.0232 & $0.0700 * *$ \\
\hline Buy Organic and Local (factor) & 0.0069 & $-0.0625^{* *}$ & $0.0617 * *$ & $0.0566 * *$ \\
\hline Donated Envir. Organiz. $(1=$ yes $)$ & -0.0475 & -0.0285 & 0.0746 & $0.1746 * *$ \\
\hline Influence Policy $(1=$ yes $)$ & $-0.0753 * *$ & 0.0069 & $0.0684^{*}$ & 0.0411 \\
\hline Predicted Probability & 0.2861 & 0.4657 & 0.2482 & 0.6217 \\
\hline Observations & 806 & 806 & 806 & 202 \\
\hline
\end{tabular}

a. *** indicates significance at $\alpha=.01, * *$ at $\alpha=.05$, and $*$ at $\alpha=.10$.

b. Discrete effects for binary variables.

c. Predicted probabilities rounded to the fourth decimal place. 
Table 5. Reasons Provided by Respondents for Not Supporting RCF-Certified Beef, Not Being Willing to Pay More for RCF-Certified Beef, or Rejecting the Specified Premium

\begin{tabular}{lll}
\hline Reasons Provided in Text & Observations & Percentage \\
\hline Does Not Support RCF-Certified Beef & & \\
\hline Not beef eater or do not care about the beef industry & 12 & $4.63 \%$ \\
Do not believe in global climate change & 44 & $16.99 \%$ \\
Beef contributes only a small amount to GHG & 24 & $9.27 \%$ \\
Cannot afford or too expensive & 58 & $22.39 \%$ \\
Do not believe in, or not interested in this program & 20 & $7.72 \%$ \\
Objection to government intervention or regulation & 35 & $13.51 \%$ \\
No answers provided/not applicable & 29 & $11.20 \%$ \\
Total & 259 & $100.00 \%$ \\
\hline Supports but Will Not Pay More for RCF-Certified Beef & & \\
\hline Cannot afford or too expensive & 224 & $54.90 \%$ \\
Objection to government intervention or regulation & 5 & $1.23 \%$ \\
No answers provided/not applicable & 68 & $16.67 \%$ \\
Total & 408 & $100.00 \%$ \\
\hline Will Not Pay Specified Premium for RCF-Certified Beef & & $20.45 \%$ \\
\hline Cannot afford or too expensive & 45 & $74.09 \%$ \\
No answers provided/not applicable & 163 & $100.00 \%$ \\
Total & 220 & \\
\hline
\end{tabular}

